\title{
Authoritarianism in Belarus: Eventual Threats to Lithuania's Security
}

\begin{abstract}
The Republic of Belarus is the most authoritarian state in Central and CentralEastern Europe. The international security community identifies the threats of Aleksandr Lukashenko's regime at global and regional levels. The article analyses the problem: what are the concrete threats posed to Lithuania by the Belarusian authoritarianism? The profiles of the problem presented here - the origins of authoritarianism in Belarus, the pattern of the dependence in the relations between Belarus and Russia, the international security community and Belarus, the development of the Lithuania-Belarus relationship - make it possible to identify eventual threats to Lithuania arising within political, social, economic and ecological sectors.
\end{abstract}

Following the recognition of the Republic of Belarus as an independent state in early 90 's, the relations between the Euro-Atlantic community and Belarus experienced steady progression. Belarus was given the associate member status in the North Atlantic Treaty Organisation Parliamentary Assembly (NATO PA). The signing of the Partnership and Cooperation Agreement (PCA) between the European Union and Belarus in 1995 signalled its commitment to political, economic and trade co-operation as significant assistance was provided to Belarus within the framework of the TACIS Programmes and also through various aid programmes and loans.

However, the progress in the EU-Belarus relations stalled after 1996, because President Aleksandr Lukashenko sharply turned the helm of the state towards authoritarianism. The associate member status of Belarus in NATO PA was suspended in 1997, following the constitutional referendum organised by Lukashenko in 1996, which authorised him "to change the rules of the game" by abolishing the existing Parliament (the convention of the $13^{\text {th }}$ Supreme Soviet), hand-picking the acquiescent National Assembly and amending the 1994 Constitution, by extending inter alia the presidential term of office from five to seven years. New regulations for parliamentary elections were eventually passed on the basis of the 1996 Constitution, making it possible to elect a new National Assembly in October 2000. However, the electoral legislation and, more importantly, the conditions in which the consultation took place were deemed by the OSCE as "short of meeting the minimum commitments for free, fair, equal, accountable, and transparent elections". Precisely the same happened during the last presidential election that took place on September 9, 2001.

"Prof., dr. Raimundas Lopata - Director of the Institute of International Relations and Political Science of the University of Vilnius. Address: Vokiečiu 10, LT-2001 Vilnius, Lithuania, tel. +3705-2514130, e-mail: raimundas.lopata@tspmi.vu.lt 
In other words, particularly during the last five or six years, the Republic of Belarus has solidified its reputation as one of the most perplexing and enigmatic countries in Europe. Belarus remains an exception, an outsider among the states of Central and Eastern Europe. Whereas almost all other states in the region have undertaken steps to implement democracy, free market reforms, and took the westward orientation (event Russia has proclaimed its West-oriented foreign policy, and even the Ukraine is trying to articulate its aspiration to join NATO in the future more clearly), Belarus has restored and resurrected the old values and principles of the Soviet Union, such as authoritarianism and state-regulated economy.

Afew days before the September 11 terrorist attacks, the United States Secretary of State Collin Powell called the dictatorial state of Belarus "the only outlaw* state of Euro$\mathrm{pe}$ ". At that time, the head of the American diplomacy emphasised a danger to the regional security in general as posed by the regime itself and the threats inherent in its origins.

The reference was primarily addressed to a militarised group established under the Ministry of Internal Affairs and charged with the execution of any assignments, including political assassinations ${ }^{2}$. The decree of Lukashenko providing for the confiscation of the property of citizens and enterprises without a court trial was not left unnoticed either. Besides, that decree, as well as the methods of political blackmail and intimidation, were extensively employed by the regime, especially in the aftermath of the September 2001 presidential election, when the heads of nine Belarusian enterprises were taken under arrest ${ }^{3}$, or when power structures regularly and without compunction quelled the events organised by the opposition.

It should be emphasised that the anxiety of the international security community has been caused not only by the unprecedented violations of human rights in Belarus. Within the context of regional security, particular attention is also given to a number of other circumstances.

First - the military power of Belarus, which far exceeds that of, for example, the neighbouring Lithuania or Latvia.

Second - open statements made by Lukashenko himself and his actions on the international scene. Reference is made here not only to the malicious and often offensive speeches of the President directed against the West, or his visit destinations -Cuba, Syria, Libya ${ }^{4}$ - but also to provocative military exercises. Thus, for example,

\footnotetext{
${ }^{1}$ Lenzi M. Iš Minsko eina tamsūs ginklų keliai (Dark Roads of Arms are going on from Minsk), Lietuvos Rytas, 1 June 2002. - No. 125.

${ }^{2}$ This was publicly announced by former interrogators of the Belarus Prosecutor's Office Oleg Sluchek and Dmitrij Petrushkevich who had asked for political assylum in the U.S. According to their information, the victims of the abovementioned group included politicians Jurij Zacharenka, Victor Gonchar, Anatolij Krasovskij, journalist Dmitrij Zavadskij. See: Vadovas giriasi abejotinais nuopelnais (the Leader is Boasting of his Doubtful Merit), Lietuvos Rytas, 19 November 2001.

${ }^{3}$ In the period between the autumn of 2001 and early 2002, there were arrested: Leonid Kalugin, director of the Minsk corporation for the production of refrigerators "Atlant", head of the Belarus railways Victor Rachmankov and his deputy Jevgenij Nazarenka, director of Minsk stadium "Traktor" Vladimir Oleinikov, director of a car dealing place "Kolco" Aleksandr Vasilevskij, general director of the Minsk enterprise for the production of tractors Michail Leonov, director of the Gomel radio enterprise Anatolij Kirikov, et al. See: Baltarusijoje - nauja suemimu banga (New Way of Arrests in Belarusia), Lietuvos Rytas, 24 November 2001.; Baltarusijos ịmonių vadovų persekiojimas - kerštas už rinkimus (Persecution of the Heads of Belarusian Enterprises - Revenge for the Elections), Lietuvos Rytas, 11 January 2002.

${ }^{4}$ And vice versa: for example, in early January 2002, Lukashenko invited Muamar al-Gaddafi, and in February the President of Iran Mohammad Katami to come to Minsk for an official visit. See: BNS information of 18 January and 14 February 2002.
} 
right before the 2001 presidential election, in the military exercise "Neman-2001" held in September Belarus simulated a repulse of a Lithuanian-Polish assault, while the scenario of the military exercise "Berezina-2002" held in early summer of 2002 included the crossing of the Berezina River and an attack westwards.

Third - the catastrophically deteriorating economic situation and the actual threat of a total economic collapse.

These are just several of the points that not only permit it to label Belarus an outlaw state, but also highlight the potential consequences for the regional securityunpredictability of the regime, political volatility, economic destabilisation and eventual refugees.

Recently, however, the validity of this assumption has become even more pronounced. The last bastion of authoritarianism in Europe ruled by Lukashenko's regime is continuing to violate international law. During the previous year, Minsk clandestinely turned into the key military supplier to $\mathrm{Iraq}^{5}$, other militant states and terrorist groups by providing them with high quality military equipment. And finally - the total disregard displayed by the official Minsk in respect of international organisations (the Organisation for Security and Cooperation in Europe Mission in Belarus has, in essence, been rendered ineffectual) that has also become evident recently.

Thus, it is obvious that the international security community perceives potential threats posed by Belarus both at global and regional levels. The problem is - what consequences on Lithuania and its security may be expected from the situation evolving in Belarus and around it?

In searching for the answer and identifying the eventual threats within definite sectors (political, military, social, economic and ecological ${ }^{6}$ ), the following aspects of the problem will be subjected to a more comprehensive analysis:

- ... The origin of the Belarusian authoritarianism and its eventual specification.

-

Belarusian-Russian relations: the pattern of dependence in theory and practice. Th e international security community and Belarus.

D y namics of the Lithuanian-Belarusian relations.

\section{The Origin of the Belarusian Authoritarianism and its Eventual Specification}

The Belarus of today presents a tricky puzzle: why has this particular way of development been chosen and what are the likely developments in the further trans-

\footnotetext{
${ }^{5}$ The Belarus-Iraq relationship received publicity in Lithuania as well. See: BNS, Seimo narys ragina daugiau aiškinti Baltarusijos gyventojams apie demokratiją (Member of Seimas Urges to Explain Democratic Values for Belarusians), 2 October 2002.

${ }^{6}$ More about the specifics of threats to (national) security, see: Buzan B. Žmonès, valstybès ir baimè. Tarptautinio saugumo studijos po Šaltojo karo (People, States and Fear: An Agenda for International Security Studies in the Post-Cold war Era). - Vilnius: Eugrimas, 1997. - P. 156-193.
} 
formation process of the regime?

Theoretical research on society transformation and democratisation processes usually distinguishes the following distinct criteria, the absence of which precludes the evolution of one or another society into a democratic society: quate economic progress; ade -

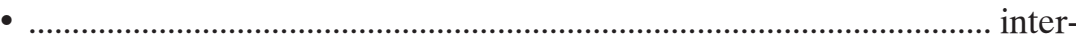
national environment (the more a country is oriented to Western- shared democratic values, the greater the prospects for democratisation to succeed);

poli-

tical traditions (whether a country has democratic traditions or not);

$\bullet$ institutional structures (parliamentary system, presidential system, etc.) ${ }^{7}$.

It is hardly necessary to prove that none of the criteria mentioned above is "operational" in Belarus. Belarus is an exception among other post-communist countries. Despite the break-up of the communist regime, political and economic power remained in the hands of the same political elite. Moreover, that elite was not forced to change.

After the failed 1991 coup d'etat in Moscow, the Belarusian nomenclature was forced to follow market reforms similar to those enforced in Russia. However, such reforms were carried out only partially. There was liberalisation of prices, but no privatisation or a tight monetary policy was pursued. The decision not to privatise state assets was determined by the aspirations of the ruling elite. Otherwise, under the conditions of free competition, most enterprises would have collapsed. Those halfreforms had a negative impact on the majority of the population as they were solely in the interests of the nomenclature. 8

The economic slump had a unifying effect on the two social forces that allowed the establishment of A. Lukashenko's regime, namely, the old nomenclature, resisting the market economy reforms, and the impoverished part of the society, bearing the brunt of the lame reforms. ${ }^{9}$

Besides, with reference to the latter, it is necessary to remind that the major part of the Belarusian society is composed of rural population, while the urban inhabitants themselves are newcomers from the provinces still guided by traditional patriarchal values. The Belarusian political scientist Viktor Chernov describes such world outlook of people as archaic conservatism and mythological way of thinking ${ }^{10}$, i.e. low demands, fear of freedom and competition, "fortress-under-siege" psychology, strive for absolute rule, inability to comprehend the importance of representative institutions, orientation

\footnotetext{
${ }^{7}$ Prezeworski A., Alvarez M., Cheibub J.A. Limongi F. What Makes Democracy Endure, Journal of Democracy (1996). - No. 7. - P. 39 - 55.

${ }^{8}$ Davidonis R. The Challenge of Belarus, and European Responses, Institute for Security Studies, Occasional Papers. - July 2001. - No. 29. - P. 5.

${ }^{9}$ Feduta A. "Sovetskije belorusy": popytka opredelenija ("Soviet Belarusians: Attempt to Identify"), Belarus Monitor, Minsk, 1999. - S. 21 - 29.

${ }^{10}$ Chernov V. Priroda Politicheskogo Rezhima v Belarusii i Perspektivy Ego Transformaciji (Origins of the Political Regime in Belarusia and its Transformation Perspectives), Belarus-Monitor, Minsk, 1997. - S. 66-67.

${ }^{11}$ Zabytyj Sosed - Belarus v Kontekste rasširenija Evropejskogo Sojuza na Vostok (Forgotten Neighbour - Belarus in the Context of the EU Enlargement). - Fundacja Batorego, - Warszawa, 2001. - S. 7.
} 
towards an authoritarian charismatic leader, loyalty to any centre of authority, high degree of adjustment to authority, passivity and compliance. That is why the authoritarian alternative imposed by Lukashenko and the idea of a union with Russia (often presented within the context of the restoration of the Soviet Union) perfectly complies with the expectations of the majority of Belarusian citizens. It is worth remembering that over 30 per cent of Belarusian people have close relatives in Russia. A lot of Belarusians have graduated from Russian higher schools, started their political or professional carreer in Russia and, finally, have served in the army together with Russians. ${ }^{11}$

Nonetheless, it is also necessary to emphasise that another generation without any nostalgic feelings towards the no longer existing USSR has grown up; they are quite well-educated, are able to use the Internet, are mobile enough to visit various European countries. Still, it should also be noted that the representatives of this generation, who predominantly reside in Minsk and almost naturally support the idea of their country's Europeanisation, do not associate themselves with the opposition and are not even inclined to trust it. This scepticism is to a great extent reinforced by the fact, that the current opposition leaders and the nucleus of the Belarusian political elite in general continue using those political and social concepts that were typical to the Soviet period. ${ }^{12}$

Researchers, however, sometimes try to resort to the regional diversity of Belarus and the regional specifics determined by historic evolution (West Belarus, i.e. Grodno and Brest regions; East Belarus, i.e. Vitebsk and Mogilev regions). Though there is an ongoing discussion on whether such specifics really exists, and if yes whether it constitutes a factor in the present political development of Belarus.

The emergence of the Lukashenko phenomenon was facilitated by other circumstances as well. It is generally explained that there were no political reforms in Belarus either. The independence was not related to an upsurge of the national movement in the country. Contrary to the neighbouring countries, the national movement in Belarus was not the main catalyst for radical changes. This was certainly mostly determined by the fact that in general it is quite complicated to talk about the traditions of statehood and national identity in relation to Belarus.

For many years, the territory comprising the present-day Belarus was part of the Grand Duchy of Lithuania, the Polish-Lithuanian Commonwealth and, later, the tsarist Russia and the USSR. The country experienced three major rebellions, two World Wars, the Bolshevik occupation, and then its status as a Republic within the USSR. In addition, Moscow pursued an active policy of Russification. These factors have had a huge impact on the Belarusian national identity or its lack thereof.

However, it is necessary to emphasise that at the very beginning of the 90's, Minsk tried to compensate the problems of national identity by means of foreign policy, particularly - by claims on the Lithuanian territory. For example, on 24 February 1992, the Belarusian Foreign Minister Piotr Krauchanka openly told a visiting European Community delegation that Belarus had doubts whether Vilnius

\footnotetext{
${ }^{12}$ Ibid. - S. 7-8.

${ }^{13}$ In essence, Minsk was a pawn in the hands of Moscow which was actually creating complications for Lithuania. The issue was resolved in 1995, when Lithuania and Belarus signed the Agreement on State Borders and some time later the Agreement on Good Neighbourly Relations and Cooperation. See more: The Belarus Issue. - Institute of International Relations and Political Science, Vilnius University, 2002. - Working Papers. - No. 1. - P. 8.
} 
lawfully belonged to the Republic of Lithuania. ${ }^{13}$

Though Lukashenko never made similar statements in respect of Lithuania, he nevertheless took advantage of the specifics of the Belarusian national identity in the market of the country's domestic policy. In the middle of the 90s, by emphasising his non-allegiance to any party, he, at the same time, chose a corresponding political motto: "I am neither with the right nor with the left, I am with the people". In a broader sense, Lukashenko took advantage of the shortcomings of the extremely weak party system. The so-called democratic forces were fragmented and headed by the leaders, whose policy was very remote from the Belarusian reality. On the other hand, until 1995, the parliament elected in the Soviet times still worked in Belarus. This communist-governed institution of power blocked the proposals of the opposition to hold election before term, thus the real power fell into the hands of the executive power.

The President is still reaping the fruits of this victory. An independent opinion survey conducted in Belarus before the last presidential election showed that if the presidential election had been held the next day, Lukashenko would have been reelected. His is still relying on rural population, impoverished workers, pensioners and the internal army. These social layers comprise the major part of the population, which find the status quo satisfactory and are opposed to any radical change. Even though there are talks about an increasing dissatisfaction among the ranks of the Belarusian nomenclature, the latter is still too weak to attempt any coup d'etat and remove Lukashenko from power. The opposition is still quite feeble and fragmented. It even failed to nominate a candidate who could offer a more or less serious competition to the incumbent president.

Some political scientists ${ }^{14}$ believe that Lukashenko, upon taking advantage of all circumstances mentioned above, has created the so-called sultanistic regime, i.e. a sub-type of the authoritarian regime, where personalised rule dominates principally in all spheres of life, where law does not apply, but a low level of institutionalisation prevails, clientelism predominates, corruption flourishes, where no clear ideology is identifiable, except laudation of the rule, etc. There is a number of well-known historic examples of such regimes: the Duvalier regime in Tahiti, the Trujillo regime in the Republic of Dominique, the Ceaushescu regime in Rumania. Experience has shown that changes of regimes in those historic situations were executed shedding blood and by means of a mass or military revolt.

As concerns possible scenarios in the case of Belarus, so far there has been no evidence of such alternative. It might be problematic to find an answer to the question of how the regime might be affected by the constantly deteriorating economic situation and even the signs of economic collapse discerned by some of experts. On the other hand, some other weaker sides of Lukashenko's regime - such as the legitimacy of his presidency - might also become more pronounced. Few doubt, however, that the development of Belarus will be determined by an aggregation of internal and

\footnotetext{
${ }^{14}$ The Belarus Issue. - Op. cit. - P. 13; Steven M.E., Taras K. Sultanism in Eastern Europe: The Socio-Political Roots of Authoritarian Populism in Belarus, Europe-Asia Studies. - 2000. - Vol. 52. - No. 3. - P. 523-547.

15 "Atskirkime muses nuo kotletu" ("Let's Distinguish between Flies and Cutlets"), Atgimimas, June 21 - 27, 2002. - No. 24. - P. 12.
} 
external factors.

Nobody questions the fact that Russia is the only force that the official Minsk takes into consideration. Nobody doubts the economic dependence of Belarus upon Russia either. Far less emphasis is given to the fact that Lukashenko employs the Russian factor as a source of his political legitimacy both inside the country and by ignoring the opinion of the West. Nevertheless, some evidence has lately surfaced permitting analysts and experts to state that this source has started gradually drying up ${ }^{15}$.

\section{Belarusian-Russian Relations: the Pattern of Dependence in Theory and Practice}

Three years ago, Lukashenko's prospects for taking the highest office in the Union of Belarus and Russia were openly discussed. A year and a half ago it was already hinted that only with the help of Moscow he was thought to able to hold power in Belarus. Today Vladimir Putin accuses Lukashenko that he is allegedly attempting to restore the Soviet Union by means of the Union of Belarus and Russia, and, by doing this, he is undermining the statehood of Russia.

In general, it is obvious that since the collapse of the USSR, Belarus has never severed its close ties with Russia. Throughout the whole period following the downfall of the communist regime, political, economic and military dependence of Belarus on Russia has always remained especially strong. As far back as in December 1993, Minsk signed the Collective Security Treaty of the Commonwealth of Independent States; in April 1994, Belarus and Russia signed the agreement on the monetary union; in April 1996, an agreement on the Russian-Belarusian Union was signed; in May 1997-the Agreement on the Statutes of the Russian-Belarusian Union; on 8 December 1999-a declaration on further integration and the agreement on the establishment of a Union state; on 30 November 2000 - the agreement on the introduction of a common currency for the Union state. Apart from these agreements, a whole range of agreements and treaties were signed (over 100, including about 20 in the security and military areas). Even though officially it is spoken about the integration of the two countries, there is no doubt, however, that models of dependence rather than those of integration function here. This dependence enables Russia to control and often also shape the processes unfolding in the internal and external policy of Belarus.

The model of dependence is based on ethno-national closeness, hyper-integration of the Belarusian economy into the Soviet system, especially into the RSFSR, and the dependence in the areas of security and defence. ${ }^{16}$ Such model allows Russia in essence to manipulate "the Belarus card" with regard to the domestic and international constellation. Thus, for example, during the time of Boris Yeltsin, in exchange for the geopolitical union, Russia used to render support to Lukashenko's regime in the amount of 1 billion US dollars a year by selling energy sources at a lower price, opening its market to Belarusian goods, and, most often, by permitting customs aut-

\footnotetext{
${ }^{16}$ Wierzbowska-Miazga A. The Republic of Belarus or the Belarusian Republic?, CES Studies, Warsaw, 2001. - P. 51-59.
} 
horities of the neighbouring state to withhold the import tax for the goods imported into the so-called Union state (actually, into Russia). In addition, by taking advantage of the customs union, enterprises established by the administration of the Belarusian President imported a great number of smuggled goods, which were sold in Russia. During Yeltsin's time, the Union supplied the Russian elite with a vision of a still powerful and influential Russia that managed not to lose everything with the disintegration of the Soviet Union. In addition, the Union was a means of blocking the eastward expansion of NATO.

With Putin becoming the President of Russia, Lukashenko was forced to bury his hopes and dreams about ruling Russia from the top of the union of the two countries. At the same time, the majority of the Russian electorate were still nostalgic about the strong-hand policy, veneration of the symbols of the past, the stern tone in communication with the West, and harnessing of the oligarchs. It should be noted that this was exactly what the President of Belarus was emphasising most in his speeches designed to attract the attention of the Russian people. The beginning of Putin's presidency was also based on the same principles. Soon Lukashenko found it increasingly difficult to find any arguments that could help him secure the favour of Russian citizens. Before the 9 September 2001 election in order to remain on the Olympus of power, he had to convince the Kremlin leader that he was the most acceptable candidate.

Lukashenko won the election. The democratic community of the West objected to the claim that it was a democratic election. ${ }^{17}$ The paradox is that the criticism directed against Lukashenko was overshadowed by other events - the terrorist attack against the United States.

Nevertheless, it did not take long for Minsk to become aware of the tendencies in the world policy that emerged in the wake of the 11 September 2001 events and their influence. This influence evolved at two levels: within the contexts of BelarusianRussian and the international security community - Belarusian relations. It is necessary to note that Lukashenko was quite quick to identify these levels himself.

In early January 2002, the Belarusian President, in defining the priorities of the country's foreign policy, made an effort to confirm the course of strengthening the Belarusian-Russian Union, the intent to restore comprehensive relations with the European Union, and declared about his resolve to develop a dialogue on equal grounds with the United States on a whole range of issues, including fight against terrorism..$^{18}$

This time Lukashenko seemed to be in possession of a weighty argument in support of his traditional appeals for creating a union state with Russia - the second instalment of the loan of 30 million US dollars recently allotted by Moscow to Belarus for financing the creation of the union state. ${ }^{19}$ However, Minsk made a mistake in assuming that it was capable of predicting the Kremlin's actions.

There still is an ongoing argument concerning Putin's motives, when he made it

\footnotetext{
${ }^{17}$ See more: Manaev O. Prezidentskyje vybory: chto bylo na samom dele (Presidential Elections: What Happened in Reality), Analiticheskij Biuleten, Minsk, 2002. - No. 1 (15). - S. 5-15.

${ }^{18}$ BNS, Lukašenka patvirtina ketinimą stiprinti Rusijos ir Baltarusijos sajungą (Lukashenko Confirms Intention to Enforce Russian - Belarusian Union), BNS, 14 January 2002.

${ }^{19} \mathrm{BNS}$, Rusija finansuoja bendros su Baltarusija valstybès kūrimo išlaidas (Russia Finances the Expenses of the Creation of Common Russian - Belarusian State), 4 January 2002.
} 
obvious in the meeting with Lukashenko in June 2002, that he did not support the aspirations of Minsk to unify Russia and Belarus as entities with equal rights. Most probably, the underlying reasons were both Moscow's active involvement in the US-led anti-terrorist coalition, the thawing in the Moscow-Washington relationship, the publicised pro-Western course in the foreign policy and the barriers erected in Belarus to prevent the Russian capital from participating in the intended privatisation of the country's strategic enterprises. Whatever the reasons, it did not take long for the Russian President to announce, that Lukashenko would not succeed in restoring the Soviet Union.

Formally, such response was provoked by the draft constitution of the Belarusian-Russian Union prepared by Minsk. It envisaged a creation of a union state, where both parties were provided with equal rights and the possibility to veto joint decisions, while the governing of the union state was expected to be executed on a rotating basis between the Russian and Belarusian Presidents changing every half a year. V.Putin was obliged to remind who was who - even upon Russia, having become poor, its economic power still exceeded that of Belarus by 30 times. The implication was more than clear-Belarus was expected to join Russia in the capacity of one of the provinces of the grand state instead of dreaming about having influence in the Kremlin. There was no room provided for the parasitizing economy of Belarus in the ambitious programme of economic growth of Russia. ${ }^{20}$

The Belarusian President retaliated after quite a lengthy pause. It is necessary to acknowledge that his speech on the Belarusian television sounded emotional and quite censorious towards Russia. He reiterated the necessity to create a union of the two states on equal grounds and stated that Belarus would never become the $90^{\text {th }}$ entity of the Russian Federation. In early September Lukashenko once again accused Moscow of dragging its feet over the plans to unify both states. "I have always been for the union, but Moscow wants to incorporate Belarus into Russia. I am not going to put up with that", he explained and added that Putin's suggestion concerning the unification (in August the Kremlin suggested to hold a referendum on the unification of the two states, and in the event of positive results - to elect one parliament and one president) was inspired by his wish to humour wealthy electors. ${ }^{21}$

It should be noted that in response to that speech, a telephone call came from the Kremlin.22 At that moment, the tension seemed to have eased. The question is for how long?

Hardly anybody doubts that Moscow's shift away from Minsk is not determined by the Belarusian economy, Putin's badly concealed contempt for Lukashenko,

\footnotetext{
${ }^{20}$ Norkus A. Maskvos antausis Minskui (Moscow Slaps Minsk in the Face), Lietuvos Rytas, 22 June 2002, No. 143 .

${ }^{21}$ V. Putinui - Minsko kaltinimai (Minsk Charges V. Putin), Lietuvos Rytas, 9 September 2002. No. 208.

${ }^{22}$ Sanko V. Kremliovskij nokdaun (Kremlin's Knock-out), Nezavisimaja Gazeta, 04.09.2002. - No. 185.

${ }^{23}$ Some Russian politicians have openly charged Putin's policy toward Lukashenko with compliance for the West. See more: Baltarusijos prezidentas gali netekti posto (President of Belarusia Can Lose the Post), Respublika, 16 August 2002.

${ }^{24}$ America's sophistications on the possibility to predict the behaviour of Sadam Hussein would be very interesting in this context. See: Whitelaw K., Mazetti M. Why War?, Cover Story. - October 14, 2002.
} 
or even the visions of the latter about the union state, but the unanswered question concerning the predictability of Lukashenko's actions and the constellation of international politics. ${ }^{23}$

It is hardly possible to disregard the opinion that Lukashenko might behave unpredictably if he feels a real personal threat from Russia $^{24}$, i.e. if in the process of creating a real Russian-Belarusian union, attempts are made to remove him from power and de facto incorporate Belarus into Russia. Lukashenko is desperately trying to stay at the helm and he quite recently stated that he "does not reject the possibility of participating in the 2006 presidential election" 25 , i.e. he does not reject the possibility of amending the provisions of the Constitution of the Belarussian Republic, which does not allow to seek a third term in office. In other words, when faced with a threat of losing power, Lukashenko may resort to unpredictable actions and provoke, for example, a local-scale military conflict.

A formal expression of the influence exerted on the regime by the international constellation was the talk between the U.S. Secretary of State Powell and the Russian Foreign Minister Ivanov and "the issue of Belarus" raised in that meeting in the context of the fate of the OSCE Mission in Minsk. This repeatedly proved that practically "the Belarus issue" on the international East-West relationship agenda acquired a particular significance within the framework of the international antiterrorist coalition initiated by the U.S. in the aftermath of the 11 September 2001 events and with the launching of a new NATO-Russia cooperation formula.

\section{The International Security Community and Belarus}

In early 2002, Minsk was subjected to a new wave of pressure from the international security community. In January, information about Belarus being involved in the illicit trade in arms appeared in American, Israeli, Polish press. ${ }^{26}$ In early February, the Head of the OSCE Parliamentary Assembly ad hoc the Working Group on Belarus Uta Capf warned that "**the failure of the official Minsk to take steps towards democratisation may result in the beginning of an ice age". ${ }^{27}$ After visiting Minsk in the middle of February, a delegation of the U.S. House of Representatives expressed its concern about the possibility of Belarus being involved in arms trafficking with the countries supporting terrorism..$^{28}$ In early March, the U.S. issued an ultimatum to Belarus demanding to end the selling of military armaments to the countries supporting terrorism. The U.S. State Department declared about America's readiness to take steps including sanctions as one of the measures - in order to prevent such activity.

\footnotetext{
${ }^{25}$ Konstitucija Lukašenkai ne kliūtis (Constitution is not an Obstacle for Lukashenko), Lietuvos Žinios, 19 September 2002. - No. 217; Žinių srautas. Minskas (News Stream. Minsk), Lietuvos Rytas, 19 September 2002. - No. 217.

${ }^{26} \mathrm{BNS}$, İrodymų, kad Baltarusija neteisètai prekiauja ginklais nèra ir negali būti,- teigia Baltarusijos URM (According to Belarusian Foreign Ministry, there are and there could be no Evidence that Belarusia is Involved in Illegal Arms Trade), 7 February 2002.

${ }^{27}$ BNS, Baltarusijos ir Vakaru santykiuose gali prasidèti ledynmetis, mano ESBP PA grupès vadove (Head of OSCE PA Thinks that Ice-Age Can Start in Belarusia - West Relations), 5 February 2002. ${ }^{28} \mathrm{BNS}$, JAV kongresmenai reiškia susirūpinima dèl galimos Baltarusijos prekybos ginklais su terorizmą remiančiomis šalimis (U.S. Congressmen Express Concern on Belarusia's Eventual Arms Trade with "Rough Countries"), 17 February 2002.
} 
What might be the consequences of this declaration, and, in general, the American-Belarusian conflict that has been evolving for some time already to the EastWest relations at large? There can be no doubt that this question is equally important for Lithuania as well.

It should be remembered that Belarus has been regarded a participant of the conventional arms market already since 1996. It is included into the list of the top ten countries exporting armaments and military equipment. The abundance of Belarusian military export resourses is determined by several factors. First, the decrease in the production of military industry after the disintegration of the USSR was less pronounced that in Russia. Second, the majority of enterprises are still under the control of the state. Third, a huge arsenal of used Russian military equipment has remained in the country.

Already in 1994, Lukashenko decided not to comply with the requirements of the Treaty on Conventional Armed Forces in Europe ${ }^{29}$ and, instead of demolishing the armaments, offered them to foreign clients. Alongside the export of this type, Minsk is deriving a considerable profit from armaments supplied to the world market and from the production of munition parts. Trade in weapons is of vital importance for Belarus in the financial aspect. According to the data presented by some Western experts, in the period between 1997 and 2000, the country might have earned about one billion U.S. dollars from the trade in armaments and equipment. It is believed that during last years, Minsk has stealthily turned into the key arms supplier for more than 500 million U.S dollars to the radical world of Islam. During last year alone, Minsk secretly sold arms to Palestinian fighters and the countries that shelter terrorists (Syria, Iran).

The establishment of Belarus in the arms export market and the trade policy it pursues, has long been causing concern to the international security community. Firstly, the performance of the country's military industry, the system of arms trade and its financing is under the cover of great secrecy. The proceeds from clandestine transactions are believed to descend into Lukashenko's shadow budget. Secondly, it is the above-mentioned Belarusian arms trade transactions with the states which are universally subjected to the United Nations arms embargo. In October 2001, for example, the Polish magazine Wpróst published information that Minsk was selling military equipment to terrorist groups in the Balkans, South America and the Middle East, arms shipments "settle down" in Sudan and even in Afghanistan.

Washington is especially concerned about Lukashenko being increasingly interested in secret cooperation with Iraq. Some menacing developments are undoubtedly related to Minsk-Baghdad deals in the area of anti-aircraft defence. In February 2002, the U.S. State Department confirmed that Iraqi anti-aircraft defence officers

\footnotetext{
${ }^{29}$ The Treaty, signed in 1990 at the initiative of the then Conference on Security and Cooperation in Europe and adapted in 1999, sets the limits on the numbers in each of the five categories of conventional armaments that are allowed to be deployed in the regions of Europe. Out of about 30 states to sign the adapted Treaty, it was ratified only by two - Belarus and the Ukraine.

${ }^{30}$ Jankauskas A. Ar JAV sustabdys ginkluotès tiekimą teroristams Europos pašoneje? (Will U.S. Stop Supply Armaments for Terrorists?), Lietuvos Rytas, 9 March 2002.
} 
were secretly trained how to use the newest anti-aircraft missile system S-300. Since early April, there have been three attempts to shoot down the planes of the United States and Great Britain patrolling over the UN-controlled non-flying area. There were over 400 such attempts in 2001. At present, when S. Hussein, in protest against Israeli military actions in the West Bank, has deployed anti-aircraft defence systems in the non-flying area, it looks like the G.W. Bush administration will have to acknowledge that the Belarusian military equipment and competence employed by Iraq pose a threat to Americans and British..$^{30}$

Some experts believe that economic sanctions might have a deterrent effect upon Minsk, i.e. they might compel Belarus to curtail or at least limit illicit arms supplies to Arab states, which are involved in conflicts, pose threats or are terrorist states. This would allegedly have a painful effect upon the export of Belarusian metallurgic products and fertilisers that account for the greatest part of foreign currency income in the Belarusian budget. Nevertheless, it is necessary to keep in mind that having distanced itself from the West and with Russia still in its rear, it is adequately resistant to any economic pressure from the West. In this case, it would be more reasonable to speak not about Western investments in Belarus or the EU aid, which is limited to humanitarian assistance and democratisation programmes, but rather about the indisputable fact that the energy sector, strongly supported by Russia, is the only factor which is still able to avert the total collapse of the Belarusian economy. ${ }^{31}$

Political measures have also been almost exhausted, as neither the suspension of the Belarusian membership in various international organisations nor protests issued by EU member states have yielded desired results. In addition, by threatening to withdraw from the OSCE, Minsk has practically paralysed the activity of the OSCE Mission in Belarus. ${ }^{32}$

By challenging Minsk, Washington took the risk to confront Moscow's interests. There are several assumptions to suggest that Russia has been taking advantage of the illegal export of the neighbouring Belarus. Firstly, Moscow, which is trying to avoid being compromised in the eyes of the international community, finds it convenient to use Minsk in the area of military trade and thus avoid international bans and restrictions. Secondly, having in mind the scope of Belarusian export, it is hardly feasible that major transactions could be carried out without Russia's assistance. Thirdly, in most cases Minsk lacks the technical capacity required to complete the assembly of military systems. Fourthly, in general, an increasingly closer military cooperation between Russia and Belarus (joint military exercises) has lately been observed. ${ }^{33}$

Thus, having in mind that Russia's interest in arms export might be not incommensurate with that of Belarus, it could be predicted that Washington might try to resolve its conflict with Minsk by means of finding agreement with Moscow. As we have seen, namely within this context, it is possible to interpret the currently observed cooling in the Moscow-Minsk relationship.

Thus, it is possible to predict that the U.S will not want to put to test the furthe-

\footnotetext{
${ }^{31}$ See more: Lenzi M. (notre 1).

${ }^{32} B N S$, Baltarusijos ministras nemato galimybès tęsti ESBO misijos veiklą, jei nebus pakeistas jos mandatas (Belarusian Minister has not Foreseen the Possibilities to Continue OSCE Mission), 13 January 2002; Konstitucija Lukašenkai ne kliūtis (Constitution is not an Obstacle for Lukashenko), Respublika, 19 September 2002. - Nr. 217.

${ }^{33}$ Jankauskas A. (note 30). Besides, a considerable part of the joint exercises take place in Kaliningrad Oblast of the Russian Federation.
} 
red strategic partnership and, most probably, will abstain from carrying out the threat to impose sanctions on Belarus. Such mutual agreement would be beneficial both for Russia and the anti-terrorist coalition. In the meantime, Russia would acquire one more lever for reinforcing its influence on Lukashenko's regime, which is craving for support. In addition, with the increase of Russian influence in Belarus, the U.S. could hope for more orderliness in the maze of arms supplies and that the channelling of weaponry into the arms of political adversaries will be put under control.

On the other hand, within the context of a military resolution of the Iraq issue, it is also possible to predict Washington taking an unbending attitude towards the official Minsk. This version could be supported by the U.S. stance in respect of Leonid Kuchma, who was suspected to have sanctioned arms sales to Hussein in 2000. In the case of Lukashenko, the spotlight should be directed not so much to the training of Iraqi anti-aircraft defense officers in Belarus, but rather to the history of a far more serious strategic threat issued by Iraq to the international community - in 1995, in direct violation of the United Nations sanctions against Baghdad, Minsk sold to Hussein's regime special diamond-tipped equipment used in the production of some components for nuclear weapons. ${ }^{34}$

Nevertheless, a pessimistic resolution of the tension in the U.S-Belarus relationship is also possible. The implementation of the Western pressure measures may fuel anti-Western sentiment in the country and provide support for the authoritarian regime. In addition, directly faced with the sternly disposed U.S., Lukashenko may become difficult to predict. Nobody can deny that he may distance himself from the Kremlin and resort to unpredictable, spontaneous actions likely to have a destabilizing effect upon other states in the region, including the NATO aspirant Lithuania.

\section{Dynamics of the Lithuanian-Belarusian Relations}

The development of the Lithuanian-Belarusian relationship could be divided into several stages: the periods of 1990-1992,1992-1995 and since 1996/97. The dynamics of the first stage was determined by the specifics of Vilnius-Moscow and Minsk-Moscow bilateral relations. The second - the Moscow-inspired political course of Minsk aimed at encouraging separatism in Lithuania. ${ }^{35}$ The third stage was characterised both by the attempts to base the relations on the principles of good neighbourhood in accordance with the Agreement on Good Neighbourly Relations and Cooperation signed on 6 February 1995 and the emerging differences in geopolitical gravitation.

It was the latter that forced to view the Belarus neighbourhood to Lithuania as extremely unfavourable within the context of political, social and economic threats.

First of all, the existence of the authoritarian regime in Belarus per se was a threat

\footnotetext{
${ }^{34}$ Lenzi M. (note 1).

${ }^{35}$ Lopata R. (ed.) National Question in Lithuania // www.nato.inf/acad/fellow/96-98/lopata.polf

${ }^{36}$ Lietuvos karines gynybos strategija (Military Defense Strategy of Lithuania). - Vilnius, 2000. P. 3, 7-8.

${ }^{37}$ Belarus reportedly possesses 1,800 battle tanks, 2,500 armoured combat vehicles, 60 military helicopters, 250 combat aircraft and about 85,000 military personnel. See more: SIPRI Yearbook 2002: Armaments, Disarmament and International Security. - Oxford University Press, 2002; The Military Balance 2000-2001. - London, Oxford University Press, 2000. - P. 87.

${ }^{38}$ The military doctrine of Belarus includes the majority of universally accepted international law provisions, though the principle of implementing the provisions of international law is not clearly established. Within this context, the facts of cooperation between Lukashenko and Hussein are most illustrative.
} 
to the whole region because of its eventual unpredictability, likewise because of the ambiguity of the consequences stemming from the creation of the Belarus-Russian union.

Belarus, undoubtedly, is the most militarised territory in the geostrategic area of Lithuania. ${ }^{36}$ The amount of strategic weapons accumulated in Belarus and its abundant military capabilities ${ }^{37}$ are a potential source of military threat. It draws attention not only because of the character of the military exercises mentioned above, but also due to the doubts of whether Minsk is always going to de facto honour the norms of international law. ${ }^{38}$

Within the framework of Lithuania's accession to the European Union and the Schengen system, it is necessary to emphasise that the absolute majority of illegal immigrants enter Lithuania from the territory of Belarus, which has not yet executed the demarcation of its state border with Lithuania. It is not possible to disregard a likely prospect that a considerable deterioration of economic situation in Belarus might result not only in a large-scale social turbulence inside the country, but also in a massive migration of Belarusians out of the country.

And finally, the factor of economic ties between Lithuania and Belarus. Even though the economic interdependence between Vilnius and Minsk is quite insignificant, threats to the energy sector of Lithuania are quite tangible. ${ }^{39}$

In addition, Lithuania clearly identifies the consequences of ecological threats arising from the neighbouring state. The economic difficulties experienced by Belarus not only render it incapable of ensuring adequate ecological supervision of the operating enterprises; it is also experiencing difficulties in disposing of the munitions still remaining from the times of the USSR..$^{40}$

Lithuania, in pursuit of its aspiration to become a member of the Euro-Atlantic institutions, to neutralise the above-mentioned threats and concurrently to earn the status of an active actor in the Eastern Baltic and Eastern European sub-regions, has put forward proposals to the international community on the practical implementation of various workable versions of the relations with Belarus ("bridge", "intermediary", "expert"). Vilnius has openly declared that the implementation of these versions is not only determined by the character of the clearly identified threats, but it is also dependent upon:

coor-

dination of the position of Lithuania in respect of Belarus with that of the Western allies by actively joining the declarations of the Euro-Atlantic community on Belarus intended to promote the development of democracy in the country and to establish criteria for the normalisation of relations, and by urging the official Minsk to pay regard to those recommendations and take concrete steps to ensure democratic development of the country and normalise relations with the international community; Lit huania's disinterestedness in the international isolation of Belarus which might have

\footnotetext{
${ }^{39}$ Reference is given here not only to the fact that the taps and gauges of the gas pipeline from Russia to Lithuania are in the territory of Belarus, but also to the fact that so far it is unclear what consequences of Lukashenko's attempts to use energy sector in the relations with Russia could be for Lithuania.

${ }^{40} \mathrm{BNS}$, Baltarusijos kariškiams iškilo šaudmenu utilizavimo problema (Belarusian Military Faces the Problem of Ammunition Utilization), 2 October 2002.

${ }^{41}$ Lithuania's Relations with Belarus and Internal situation in Belarus. - Druskininkai, 2002. - P. 1-6.
} 
a negative effect on the democratisation of the country, on the normalisation of its relations with the countries of the West and concurrently on the stability and security both of Europe and the region.

These motives as well as the practical experience of relationship with Belarus have shaped a particular attitude of Vilnius in respect of Minsk - to pursue the policy of pragmatic selective cooperation. ${ }^{41}$ In practice, it means that the political cooperation with Belarus ought to be minimal (e.g. there have been no exchange of visits between the official heads of states or high-standing officials since the end of 2000), at the same time maintaining ties with separate power structures of Belarus and developing bilateral cooperation in those areas which are important for the security and stability not only of Lithuania, but also of the whole region (demarcation of state borders, illegal migration, regional cooperation, energy issues, etc.), irrespective of the direction of the political development of Belarus.

During its presidency in the Council of Europe in the first half of 2002, Lithuania was trying to emphasise namely this political line in its relations with Belarus. Despite a positive evaluation ${ }^{42}$, the prospects for this line are still quite obscure, as there is a certain ambiguity regarding potential priorities in the policy of the international security community in respect of Belarus ${ }^{43}$.

\section{Conclusions}

Belarus is the most authoritarian state in Central and Central-Eastern Europe. The threats arising from Aleksandr Lukashenko's regime are identified by the international security community at global and regional levels. These threats arise not only because of the existence of the authoritarian regime in Belarus per se, but also out of the unpredictability of this regime in internal and external policy.

Namely the unpredictability of Lukashenko's regime in the spheres of domestic and foreign policy, political spontaneity, potentiality of employing the military sector for the legitimisation of the regime, threat of economic collapse, uncontrollable character of social consequences - all this poses particularly tangible threats to Lithuania.

In this situation, the strategy of pragmatic selective cooperation pursued by Vilnius is likely to be successful only if the international security community possesses levers of substantive influence on the evolution of Lukashenko's regime.

\footnotetext{
${ }^{42}$ BNS, Lietuvos ministras Strasbūre pristate ET pirmininkavimo prioritetus (Lithuanian Minister Has Presented Priorities of CoE Chairmanship), 22 January 2002.

${ }^{43}$ The materials of the round-table discussions "Cooperation with Belarus: Experience and Prospects" organised by the Institute of International Relations and Political Science of Vilnius University. - Druskininkai, 1-3 March 2002.
} 